\title{
Moral Responsibility: The Missing Element in Educational Leadership
}

\author{
Christopher Vasillopulos ${ }^{1} \&$ Morgan Denney ${ }^{2}$ \\ ${ }^{1}$ Eastern Connecticut State University, USA \\ ${ }^{2}$ Grand Canyon University, USA \\ Correspondence: Christopher Vasillopulos, Political Science, Eastern Connecticut State University, Willimantic, \\ CT, USA. E-mail: vasillopuloc@easternct.edu
}

Received: December 14, 2012 Accepted: January 3, 2013 Online Published: March 25, 2013

doi:10.5539/hes.v3n2p74 URL: http://dx.doi.org/10.5539/hes.v3n2p74

\begin{abstract}
We intend to deepen the understanding of leadership in general and educational leadership in particular by an analysis of Chester Barnard's (1938) concept of executive responsibility. By so doing we believe that we will reveal how an educational leader can foster the environment in which competent teachers can optimize their students' learning experience. We will contend that Barnard's (1938) theory of executive leadership and organizational effectiveness would have dealt much better with the dilemmas of Billy Budd than either Rand (1957) or Gomba (2012) and by extension would deal much better with the kind of organization either would suited to their models.
\end{abstract}

Keywords: educational leadership, servant leadership, Ayn Rand, Chester Bernard, Billy Budd

Persons as participants in specific cooperative systems are regarded in there purely functional aspects, as phases of cooperation... as outside any specific organization, a person is regarded as a unique individuation of physical, biological, and social factors, possessing in limited degree a power of choice... Both are always present in cooperative systems (Barnard, 1938).

\section{Introduction}

Although leadership is not a new concern in educational circles, the literature on the concept has burgeoned over the past few years. In a rapidly changing world, saddled with precarious economies, political upheaval and a variety of problems more directly related to education, schools have been driven to reconsider academic leadership. The hope is that something called 'leadership' or some new kind of 'leader' will be able to deal with the problems besetting education in the $21^{\text {st }}$ century. Just as there seems to be a consensus that education consisting of 'skill and drill' is no longer adequate, there seems to be an appreciation that old fashioned principals and superintendents will not be able to handle the demands of the new century. We agree with the need for fundamental change in educational practice, we also believe, however, that these changes will be misconceived or when well-conceived will founder on an inadequate understanding of schools as organizations.

There is a consensus that the prime directive of schools is to create an atmosphere in which competent teachers can optimize learning for their students. Increasingly, the corollary of this consensus is that educational leadership is essential to the fulfillment of this objective. In other words, placing a competent teacher in a classroom is not sufficient for learning to take place. Something more is needed: leadership. A review of the literature seems, however, to indicate a widespread misunderstanding or inadequate understanding of the concept of leadership. Without a deeper understanding of leadership, to speak of educational leadership seems futile. In these circumstances, it is not surprising that much of the literature, including that which calls for radical or structural changes, conceives of educational leadership in traditional terms, largely unchanged, despite protestations to the contrary, from the late $19^{\text {th }}$ and $20^{\text {th }}$ centuries (English, 2011). We intend to deepen the understanding of leadership in general and educational leadership in particular by an analysis of Chester Barnard's (1938) concept of executive responsibility. By so doing we believe that we will reveal how an educational leader can foster the environment in which competent teachers can optimize their students' learning experience. Good theory leads to good practice.

There seems to be a consensus that creating an optimum learning environment is the prime moral responsibility of leadership. Our difficulty is not with this important objective as stated, but with leaving it at that. For as such very little is said beyond: (1) schools are institutions of learning; (2) it is important that learning takes place there; 
(3) school leaders are obliged to fulfill this mandate; and (4) leaders should lead. All of these points are valid, but they do little more than define what a school is when it has a person responsible for fulfilling its mandate. So limited, these points are not very helpful at either a practical or theoretical level. This conclusion is reinforced by the frequently iterated laundry lists of an educational leader's responsibilities. A relatively sophisticated list follows:

[Leaders] (1) 'set the organizational direction and culture that influences how teachers perform; (2) break down boundaries and other walls of separation and isolation by building of inclusiveness...'; (3) [provide] 'guidance and direction of instructional improvement;' (4) 'to foster exceptional performance within organizations;' (4) a powerful portfolio of beliefs and values such as justice, community and schools that function for all children and youth;' (5) to maintain 'a critical capacity, foster a sense of possibilities' (Slayton and Mathis, 20100, p. 28-29).

Lists like this are unexceptional, but they are little more than 'politically correct' job descriptions. When lists like this occur in articles which stress the need for radical change or innovation in schools, they seem to undermine the objectives of the articles. It is difficult to see how a job description consisting of these vague objectives can get beyond traditional notions of education. In this article we present a concept of educational leadership which we believe can move in this direction. If schools need to reflect the needs of the $21^{\text {st }}$ century, concepts of educational leadership must be altered to meet these needs. This alteration must begin with a Barnardian understanding of authority, the conditions of cooperation, organizational effectiveness, the creation of moral codes, the irreducible freedom of the individual - all in the context of a liberal society. We try in this essay to contribute to this process.

We will first posit two kinds of leadership: servant leadership and Ayn Rand's (1957) version of capitalist executive command. We will then examine why neither can account for the issues of leadership, justice, or organizational effectiveness in Melville's (1950) Billy Budd. In brief each approach has a critical missing element. We then consider leadership in the context of the thought of Chester Barnard (1938). We will argue that his soundly grounded concepts of leadership and authority will apply to an educational setting. We believe the failure of leadership in Billy Budd will deepen an appreciation of what educational leadership must mean if it is to fulfill the prime objective of schools: to create an optimum setting for learning. In other words, unless leadership, authority, and the executive's moral responsibility are understood, no organization can hope to be effective. Schools as organizations must be understood with the depth of Barnard's analysis, if the concept of educational leadership can become more than a list of well meaning attributes.

Jesus' leadership style may not have been bounded by servant leadership... but for a modern audience seeking leadership understanding, an in depth study of Jesus' leadership style would be invaluable (Gomba, 2012).

To the glory of mankind, there was, for the first and only time in history, a country of money - and I have no higher, more reverent tribute to pay to America, for this means: a country of reason, freedom, production, achievement (Rand, 1957).

\section{Two Kinds of Leadership: Atlas Shrugged and Servant Leadership}

Here we describe two kinds of leadership, admittedly extreme. To the degree that left and right makes sense, Ayn Rand (1957) is at the right pole and Sister Gomba (2012), the left. We believe that the discussion of these outliers is useful, because the many more centrist approaches, in their efforts to be reasonable and pay attention to the complexity of human situations, are often inconsistent or vague. Extremes offer the virtue of clarity. Moreover, they provide benchmarks by which to classify more moderate approaches, most of which lean in one direction or the other. The extremes are not concerned with revealing too much of their underlying assumptions, values or proclivities. They are true believers and therefore do not mind being 'in your face.' Rand (1957) has countless statements regarding the necessary absence of 'sentiment' for any proper and 'moral' decision. 'I am not interested in helping anybody. I am interested in making money' (Rand, 1957, p. 22). 'I intended to give you the battle of your life... I intended to cut into your business and squeeze you to the wall and drive you out if necessary' (p. 80). 'We haven't any spiritual goals or qualities. All we're after is material things. That's all we care for' (p. 87). These are not the words of the villains of Atlas Shrugged, but of its heroes. The villains, or the' looters,' as Rand calls them, speak the language of social justice, humanity and the people. The apogee of her views comes in a tour de force, which we cannot quote in full:

'To trade by means of money is the code of men of good will. Money rests on the axiom that every man is the owner of his mind and his effort. Money allows no power to prescribe the value of your effort except the voluntary choice of the man who is willing to trade you his effort in return... Money is the scourge of 
the men who attempt to reverse the law of causality - the men who seek to replace mind by seizing the products of mind... Then you will see the rise of the men of the double standard - the men who live by force, yet count on those who live by trade to create the value of their looted money- the men who are the hitchhikers of virtue. In a moral society, these are the criminals and the statutes are written to protect you against them' (Rand, 1957, p. 410-413).

At the opposite extreme, Gomba (2012) draws the logical conclusion of servant leadership by associating it with Jesus. Although we cannot avoid references to the underlying values of these leadership theories, a comprehensive account is well beyond the scope of this paper. We risk unfairness to Rand (1957) and Gomba (2012), because we use them as means to make our interpretation of Barnardian organization cogent, not to build upon them. By illustrating the weakness of each extreme view and by extension their associates closer to the middle, we offer a Barnardian alternative, which may seem all the more convincing after revealing the inadequacies of Rand's (1957) and Gomba's (2012) positions, while remaining cognizant of the truncated versions of their thought.

Our 'data base' is Melville's BillyBudd. Our analysis demonstrates the limitations of both Rand's (1957) and Gomba's(2012) understandings of leadership in complex organizations. A navy ship is neither a capitalist nor a welfare organization. It falls outside the 'ideal-type organization' of both Gomba (2012) and Rand (1957). Yet, we will contend that it will reveal the limitations of both approaches, even in organizations which closely conform to their preferred organizations. Rand's (1957) approach cannot adequately account for the leadership of an effective profit-driven organization, no matter how hard-bitten. Gomba's (2012) cannot account for the leadership of the most therapeutically-driven organization, no matter how Christ-like. They fail for the same reasons: an insufficient appreciation of human nature and the multivariate values and objectives that reside in modern life. Both Rand (1957) and Gomba (2012), especially in our sketches of them, strip choice of its necessary complexities, although they do so from opposite directions: Rand (1957), from the perspective of an ego-driven profit-making achiever; Gomba (2012), from the perspective of a self-abnegating saint. We will contend that Barnard's (1938) theory of executive leadership and organizational effectiveness would have dealt much better with the dilemmas of Billy Budd than either Rand (1957) or Gomba (2012) and by extension would deal much better with the kind of organization either would suited to their models.

I will never live for the sake of another man or ask another man to live for me. (Ayn Rand)

\section{Atlas Shrugged: Heroic Materialism: The Ego Unchained}

This eleven hundred page masterpiece, written with great perceptiveness and in stunning detail, centers on the destruction of the greatest economy in the world and its greatest city, New York. A 'people's government' loosely modeled on Roosevelt's New Deal, verging on caricature perhaps, but which nevertheless captures the underlying values of many of its 'socialist' office-holders, most evident in the first four years of the New Deal (Schlesinger, 1958). The mantras were: the Public Welfare, the Public Interest; Social Justice; Expert Planning; the Bankruptcy of Capitalism, especially Wall Street and the major corporations; the Attack on Reactionary Courts which preferred Capital to People; the Attack on the Constitutional limitations on the exercise of democratic majority government; the Need to Regulate the Economy, and the like. Rand (1957) mercilessly and brilliantly annihilates these 'ideas' and their underlying values. A weak, but essentially self-healing free market economy is 'looted' in the name of the People, destroying the prosperity of all, except 'the looter's' who run the government. The economy no long runs according to supply and demand and the profoundly rational 'genius of the producers,' it runs or rather runs down according to the need to secure governmental approval for any significant decision. In its effort to apply the Marxist mantra of 'from each according to his ability, to each according to his need,' the economy driven by profit becomes the economy driven by 'pull.' The Adam Smith's fundamental truth of that the baker, butcher et al, supply their customers out of self-interest, not regard for the public welfare, is transformed into an expression of greed. The most successful become the incarnation of evil. The 'producers' are sacrificed to the 'takers;' the creative to the dullards; the ambitious, disciplined and hard working to the lazy, all in the name of the People.

Moreover, Rand (1957) takes her devastating critique of a government-run economy further by praising the harshest expressions of laissez-faire capitalism: cut-throat competition, opportunistic advantage, the necessity to earn respect, even within families and the circle of friends, the cost-benefit analysis of all decisions, public and private, the beauty and morality of profit, the heroism of ego-driven achievers, the power of reason, the weakness of sentiment, the fallacy of charity, and much more. Love, though seldom expressed, exists. But it is remarkably 'rational,' self-serving, even or especially when sexually charged. The word 'intimacy' does not appear. The stronger the ego, the stronger the sexual satisfaction. Otherwise, the sparingly used word, 'love' 
occurs as the deepest form of 'earned respect,' as between the self-made coal magnate and the self-made steel magnate. Yet this 'love' does not lessen the desire of the 'lovers' to take opportunistic advantage of each other. This is very far from Aristotle's notion of friendship, wherein friends seek the best for each other (Edel, 1982). In Rand's (1957) vision, what is best is for all, including friends to be apprised that each will take advantage of the other. The most extreme version of egotistic self-interest is limited only by the stricture of honest dealing. In all relations, self-interest is moral and to act in any other way is not only foolish but immoral. The best expression is summed up by several of Rand's (1957) tycoons as:' I exert my best efforts in expectation that you will exert your best efforts.' In a competitive environment, this means, 'if it is to my advantage to drive you to the wall, I will.' Rand (1957) is nothing if not brutally frank, driving every value to its logical conclusion without apology. All of these attitudes, assumptions and values amount to a heroic individualism that recalls the warrior culture of Homer's Iliad, overlaid with a Nietzschean 'immoralism' transposed to a modern economy.

'The great leader is seen as a servant first, and that simple fact is the key to his greatness' (Greenleaf, 1997).

\section{Jesus: The Servant Leader}

We find it difficult to describe Sister Gomba's (2012) notion of servant leadership for two reasons: (1) it is so open-hearted, well-meaning, and Christian that its description in an analytical essay seems mean-spirited; (2) this feeling is magnified when we subject servant leadership to scrutiny and find that it is an inadequate account of leadership in effective organizations and, perhaps worse, is in principle unable to do so. Yet girding our loins, we must proceed, again for two reasons: (1) servant leadership illustrates the power of Barnardian analysis, if only by contrast; (2) it reveals elements of human nature and organizational behavior that Rand studiously denies, ignores or excoriates. We are not suggesting that a 'compromise' is possible or desirable between Rand and Gomba; nor that they can be by some 'algebraic calculation' be reconciled; nor that it would be useful to do so. On the contrary, we must preserve the profound contradictions between Rand and Gomba, if we are to retain the values of each. A watered downs version of either would simply reflect the vague and essentially useless leadership views which prevail, especially in the educational literature. It is time, past time, to get beyond the 'laundry lists' of desirable attributes of educational leaders. First, however, we must consider Sister Gomba (2012) in her own terms. Perhaps the best way is to present a series of quotations which illustrate her values, assumptions and approach:

'Leadership, based on serving others and putting their needs before one's own goes back to a paradoxical leadership style found in the life and teaching of Jesus' (Gomba, 2012, p. 232).

'A servant leader is a person who is a good listener, is empathetic, has the ability to heal relationships, can persuade and convince others, is committed to the professional and personal growth of others, is a good steward of resources, and is a community builder' (Gomba, 2012, p. 236).

'Some characteristics of servant leaders namely: love, humility, trust, and stewardship...' (Gomba, 2012, p. 236).

'Hence, the focus of servant leadership, first and foremost, is on individual followers, and takes precedence over organizational objectives' (Gomba, 2012, p. 239).

'Natural servants are trying to see clearly the world as it is and are listening carefully to prophetic voices that are speaking now' (Gomba, quoting Greenleaf, 2012, p. 240).

'The sine qua non of servant leadership is followers' holistic moral and ethical development' (Gomba, 2012, p. 240).

'We argue that spirituality is an important source of motivation for servant leaders' (Gomba, 2012, p. 244).

'There are people who are highly career minded, people whose main motivation is to get them to a position where they will gain some reward. This is the complete opposite of the spirit of servant leadership' (Gomba, 2012, p. 250).

We will not criticize these quotations. Rather we will evaluate their adequacy for dealing with and perhaps preventing the unfolding tragedy of Billy Budd.

'The moral nature was seldom out of keeping with the physical make. Indeed, except as toned by the nature of the former, the comeliness and power, always attractive in masculine conjunction, hardly could have drawn the sort of honest homage the Handsome Sailor in some examples received from his less gifted associates' ( Melville, 1950). 


\section{Billy Budd: The Story}

We, of course, encourage a fresh reading of the novella, as we can only give a bare summary of it here. Billy was a young, fit, handsome, cheerful, fair-haired sailor on the English merchant ship, the Rights of Man. By all accounts, he was a charismatic figure, though he was no official leader. His example, his competence, his demeanor and his attitudes influenced all who encountered him. 'The Rights' was intercepted by a British warship, HMS Indomitable. Billy was impressed into the British navy. On his new ship, he aroused the admiration of all, except the Master of Arms, John Claggart, whose resentment motivated him to conspire against Billy. In the presence of Captain Vere, Claggart accused Billy of mutiny. Billy, struck dumb, killed Claggart with a blow to the head. Vere immediately convened a Drum Head Court, secretly tried and convicted Billy of murder, who was executed the next morning.

Some background to these events might be useful. Britain was in 1797 at war with France and had recently put down two mutinies with great severity. The treatment of British sailors, over and above the rigors of naval warfare, was abominable. Thus the basis for mutiny was evident and would in time instigate reform. In the meantime, every British ship was a powder keg awaiting a match. Claggart was universally recognized as a malicious, if competent, Master of Arms, a naval policeman. Cruel to subordinates, obsequious to superiors, he embodied the authoritarian personality. He hated Billy. Dansker, an experience, older sailor, recognized Claggart's evil and warned an incredulous Billy that he was in danger. The officers, who also admired Billy and despised Claggart, refused to believe that Billy was guilty, notwithstanding causing Claggart's death. They knew Claggart had falsely accused Billy and that Billy was provoked to strike the Master of Arms. They conveyed, albeit weakly, their views to the Captain, who declared them irrelevant. The crew witnessed the execution which they considered an outrageous miscarriage of justice. Captain Vere died in a naval battle a little later.

'One person excepted the Master-at-Arms was perhaps the only man in the ship intellectually capable of adequately appreciating the moral phenomenon presented in Billy Budd' (Melville, 1950)

\section{Billy Budd: A Role for the Servant Leader?}

If Captain Vere had been a servant leader, could he have created an organization which would have avoided the tragedy of Billy Budd? There is no question that Vere was a flawed and failed leader. The issue is whether a course in servant leadership would have remedied his defects. The question is not as simple as it may seem. Melville suggested an alternate style of command by his description of Captain Graveling:

'The shipmaster was one of those worthy mortals found in every vocation even the humbler ones- the sort of person everybody agrees in calling "a respectable man... Here was nothing this honest soul at heart loved more than simple peace and quiet... He had much prudence, much conscientiousness, and there were occasions when these virtues were the cause of overmuch disquietude in him"' (Melville, 1950, p. 292-293)

Graveling well appreciated Billy's salutary effects on the crew, effects that Gomba (2012) might well call, 'spiritual' or echo what others have said of Billy's 'Christ-like' nature. 'But Billy came; and it was like a Catholic priest striking peace in an Irish shindy' (Melville, 1950, p. 294). Nor would Billy's tendency to express himself physically have discountenanced Graveling. When Billy thrashed a tormentor, Red Whiskers, there was no continuing discord (p. 294). Red Whiskers and Billy became fast friends under Graveling's benign leadership. There is no reason to believe that Graveling had he been in Vere's position would have acted as precipitously or anxiously as Vere. Nor does it seem likely that Graveling would have allowed someone like Claggart to exercise his baleful influence. Moreover, it seems likely that Graveling would have encouraged his officers to speak their minds and follow their instincts with regard to normal shipboard conflicts. Even Dansker might have screwed up the courage to notify an officer of Claggart's antagonism toward Billy. Even discounting the differences between a merchant ship and a war ship, it seems reasonable to conclude that Graveling's style of leadership would have improved the general atmosphere and organizational effectiveness of a warship. This is no reason to conclude that Graveling was a servant leader or that servant leadership would have improved matters. We leave the discussion why for a later analysis.

Although the contrast between Graveling and Vere is stark, on one important issue they were in agreement: Billy's unusual nature and his salutary effects on officers and crew. It is clear that Vere was not a typical aristocratic officer, who held his social inferiors in contempt and who served only his own ambitions:

'Aside from his qualities as a sea-officer Captain Vere was an exceptional character... He had a marked leaning towards everything intellectual. He loved books, never going to sea without a newly replenished library, compact but of the best... While other members of that aristocracy to which by birth he belonged were incensed at the innovators mainly because their theories were inimical to the privileged classes, not 
alone Captain Vere disinterestedly opposed them because they seemed to him incapable of embodiment in lasting institutions, but at war with the peace of the world and the true welfare of mankind' (Melville, 1950, p. 308-309).

Nevertheless, it seems very unlikely that Vere could have become a servant leader or even an 'avuncular' leader like Graveling. On a warship, it is simply impossible to fulfill the requirements of servant leadership. Although a somewhat different style of leadership might have fostered a greater degree of trust among the men and between the men and the officers, the circumstances of naval combat would have precluded almost all of the provisions of servant leadership. A warship may be the least conducive of all organizations to a 'therapeutic' style. It should be said, however, that Gomba makes no such exception.

Although we believe servant leadership has little relevance to a navy ship, we do not dismiss its values out of hand. Melville (1950) left no doubt that some of its values would have been beneficial both in terms of personal relations and morale and in terms of facilitating the cooperation necessary to accomplish complex and dangerous tasks. At its highest level cooperation approximates a brotherhood. There is no doubt that Billy helped transform his crews into 'brotherhoods.' Although the term derives from the anthropological literature of men's societies, a 'brotherhood,' with the exception of monastic orders, is the sum of human cooperative activity and the moral climate of which it is the cause and the effect. It is what enables otherwise dangerous men to live together and work together in the ways proven adaptive to the species. It's what enables human beings to produce and reproduce in the unique manner which has made them the most successful large species the world has ever known. A brotherhood provides the restraint necessary for potentially mutually destructive adversaries to cooperate without giving up the weapons otherwise necessary for survival. A brotherhood can exist without Billy's - indeed its strength is that it requires no special traits. Nevertheless, when a 'Billy' happens along, a brotherhood blossoms as never before. His physical and moral arête seems a metaphor for the highest potential of human cooperation, especially its capacity to overcome Hobbesian alienation and fear. Billy confirmed the self-image of the crews of the Rights of Man and the defects of the HMS Indomitable.

So we do not disagree with Gomba (2012) regarding the reality or the power of 'non-material' or, what she calls, 'spiritual' forces. We disagree with her when she ignores or radically subordinates organizational objectives to the 'therapy' of employees. Her employees are not those enlisted by an organization in a cooperative effort to achieve complex tasks, first and foremost. They are conceived as patients, clients or customers. The organization's main goal is to work for them; upon success it may then achieve its organizational objectives. This misconception of organizational objectives and the difference between employees on the one hand and patients, clients and customers on the other seems fatal to servant leadership.

To make this point clearer, consider 'therapeutic' organizations like hospitals or mental health clinics. The organizational objective of such organizations is primarily the care of its patients. The entire mission of such organizations is to heal or to provide therapy. So, if servant leadership has a role, one would expect it to find a sympathetic home here. But, is it the goal of these 'therapeutic' organizations to provide 'therapy' for its employees to any significantly greater degree than non-therapeutic organizations? This seems problematic at best. Can one imagine a servant leader counseling a surgeon or a psychiatrist? Can one imagine a hospital administrator subordinating organizational objectives in order to heal an employee? Here, as in other kinds of organizations, the confusion or at least the diminution of the distinction between patients, et al and employees reduces servant leadership to a generalized managerial interest in employee morale.

"Personal prudence even when dictated by quite other than selfish considerations is surely no special virtue in a military man; while an excessive love of glory, impassioning a less burning impulse the honest sense of duty, is the first" (Melville, 1950).

\section{Rand's Heroic Individualism: The Primacy of the Mission}

The mission of a war ship is to defeat the enemy. Its means are material, ships, cannon, etc. and manpower, seamen and officers. Naval leadership is strictly hierarchical; perhaps more so than any other branch of the military. The captain has all but absolute power to enforce his will; his word is law. While subject to naval regulations, the captain's interpretation of these, especially in time of war, is virtually unlimited. The threat of mutiny, as it loomed during the Napoleonic wars, added to the already heightened wartime tensions of the fleet. One can hardly imagine a more propitious setting for the application of executive discretion in the pursuit of the mission. The naval captain is the heroic leader virtually by definition, the individual who bears the absolute responsibility for his ship's effectiveness. A captain of industry, by contrast, does not have the same degree of control, because he/she cannot command coercive force, but must supply incentives or inducements to secure employee cooperation. In a profound sense, seamen are 'captives,' persons to whom the civilian citizens' rights 
do not apply, except in a highly restricted form. The warrior culture of a warship conforms to the culture of heroic capitalism with the addition of the captain's ability to enforce life and death orders. If Rand's (1957) model of individualistic leadership were to select an ideal setting, it could do no better than a navy ship in time of war.

Although the measures of effectiveness differ, profits and victory, both the corporate executive and the naval captain are evaluated by results. Has the mission been completed? Did executive decision help or hinder the accomplishment of the mission? From this perspective, Captain Vere's decision to try, condemn, and execute Billy met the criterion of heroic individualist leadership. He acted swiftly, decisively, and effectively, well within the parameters of his authority. A clear success. Yet, why does this finding leave even the most tough-minded analysts uneasy. The short answer is that leadership is seldom so simple, especially when it results in the death of one's own. Melville's (1950) disquiet is established by how much of Billy Budd deals with matters ancillary to the central issue of crime and punishment. Note the discussion of the concept of the 'Handsome Sailor.' Note the characterizations, not only of the principals, Vere, Billy, Claggart, but of the doctor, Dansker and the other officers. Note the discussion of the Rights of Man and Captain Graveling. Note the disquiet of the crew over what to them was a manifest injustice. 'Vere instinctively rejects the ambiguity of murderous innocence. Before his court, he argues for the repudiation of all considerations that take into account Billy's angelic nature, which he acknowledges to be the sacred dimension of the murder, in favor of a strict focus upon the requirements of the Mutiny Act' (Ruttenburg, 1994, p. 89). No one, not even Vere, was content with the outcome. And the discontent went much deeper than regret attendant upon the intractability of the circumstances of men at war. A profound wrong had been done, a wrong which no one was ready to justify, beyond Vere's bald assertion of necessity.

No one questioned the need for discipline or punishment. No one questioned the 'police power' of Captain Vere. Yet, instead of providing justification for the precipitous execution of Billy, the unquestioned nature of the Captain's power seemed to cast doubt on his decision among officers and men alike. Vere's orders were obeyed with varying degrees of assent, but they were obeyed essentially under duress, duress which seemed inappropriate and artificially contrived. 'Starry Vere and here the appellation seems decisive, for all his competence and intellect, was not of the sea and was not of the men of the sea. Of course, it must be understood that coercion undergirds all law and all military commands. But there is much more to leadership than lawful orders. No effective leader relies exclusively or routinely on the whip and the pistol. Effective leaders secure or induce 'willing compliance' even when circumstances are overlaid with imminent danger and the seamen are not volunteers. The more willing compliance, the less the need for 'police' supervision, and in consequence both organizational efficiency and effectiveness benefit. The grudging, sullen acceptance of Billy's execution by the crew would have imposed a 'cost' on their effectiveness and therefore on the ship's mission. The less hostile, but perhaps more corrosive, reaction of the officers of the ship also would have imposed a 'cost.' Melville's (1950) coda deserves quotation: 'The spar from which the foretopman was suspended was for some years kept trace of by the blue jackets. Their knowledge followed it from ship to dock-yard and again from dock-yard to ship... To them a chip of it was a piece of the Cross' (p. 374).The official report of these events grossly distorted the truth, averring that "alien" Budd "stabbed Claggart in the heart," proving the "extreme depravity" of the murderer (p. 373). The need to obliterate the truth testifies to the disquiet felt by the admiralty when faced by even Vere's version of the facts. Palpable injustice must be covered up in the name of military discipline and organizational effectiveness. It would be difficult to pay greater tribute to the idea that injustice exacts a price. These consequences were beyond the scope of Melville's (1950) story. He dealt with them summarily by noting Vere's death weeks after Billy's execution. In contrapuntal response, somewhat delayed, Vere's last words intoned, “"Billy Budd, Billy Budd”, to Billy's, "God bless you, Captain Vere."”

'No arts; no letters; no society; and which is worst of all continual fear and danger of violent death: the life of man is solitary, poor, nasty, brutish and short' (Hobbes, 2004)

\section{The Barnardian Alternative}

Following Aristotle by 2400 years and anticipating the last fifty years of evolutionary psychology and neuroscience, Barnard develops his theory of organizations around a sophisticated notion of human nature (Pinker, 2003). "We mean by individual a single, unique, independent, isolated, whole thing, embodying innumerable forces and materials past and present which are physical, biological and social factors" (Barnard, 1938, p. 12). Although Barnard would draw far different inferences from this individualistic conception of human nature than Rand (1957), by itself it comports almost exactly with her ideas. Moreover, Barnard (1938) derives a seemingly harsh inference from his conception of human nature, one which resonates with Rand's (1957) attitude toward the 'takers' and 'looters:' 
'Hence the idea of free will is inculcated in the doctrines of personal responsibility, of moral responsibility and of legal responsibility. This seems necessary to preserve a sense of personal integrity. It is an induction from experience that the destruction of personal integrity is the destruction of the power of adaptation... Persons who have no sense of ego, who are lacking in self-respect, who believe that what they do or think is unimportant, have no initiative whatever, are problems, pathological cases, insane, not of this world, unfitted for cooperation' (Barnard, 1938, p. 13).

Barnard does not, however, agree with either Hobbes's or Rand's conviction that the vast majority of human beings must be coerced or driven by poverty to work or obey the law. Ultimately, he agrees with Pinker (2003): "Peaceful coexistence then does not have to come from pounding selfish desires out of people. It can come from pitting some desires, the desire for safety, the benefits of cooperation, the ability to formulate and recognize universal codes of behavior, against the desire for immediate gain" (p. 169).

Let us sketch how Barnard (1938) derives human cooperation from his seminal idea of what an organization is: 'A formal organization is a system of consciously coordinated activities or forces of two or more persons' ( $\mathrm{p}$. 73). It is important to appreciate that Barnard (1938) does not base his analysis on the suppression of human nature, which he takes as highly and properly individualistic: 'A cooperative system is incessantly dynamic, a process of continual readjustment to physical, biological, and social environments as a whole. Its purpose is the satisfaction of individuals, and its efficiency requires that its effect be to change the history of the environment as a whole...' (p. 59). Note how closely Barnard (1938) comports with Aristotle's notion of the complexity of human choice:

'Ethics in the Aristotelian tradition is not a separate province in which a freely willing moral agent struggles within himself in a fretful effort to do honor to or conform to a universally binding moral law or even calculate profit and loss. It is a sober reckoning, within the communal life, of policy and the whole domain of practice: goals of life and types of character they call forth both in personal development and in institutional relations, modes of decision and guidance of conduct, problems of internal conflict and ultimate reflections on well-being' (Edel, 1982, p. 250).

The reason for this convergence of view is both simple and profound: for Aristotle, Rand, Pinker, and Barnard, the essence of being human is Reason, the foundation of informed or rational choice. This does not mean of course that all humans employ their reason properly or even frequently. It does mean that when acting qua human, the capacity for informed choice is available; it's on the human menu. For Rand (1938), this implies a radical version of ego-driven self-interest, measured by gain. Aristotle, Pinker and Barnard have a more complex understanding of the self, so they cannot infer a monocausal or what Rand would call, an objectivist, appreciation of rational choice. For them it is rational to evaluate the entire existential circumstance when trying to make an informed choice. We are not driven by material self-interest even when we remain rational. It is rational to make 'sacrifices' for family and friends under the strictures of 'reciprocal altruism' (Trivers, 1985).

Although Barnard (1938) does not use this term made famous by Trivers, it is incorporated in his idea of an organization:

'Willingness to cooperate, positive or negative, is the expression of the net satisfactions or dissatisfactions experienced or anticipated by each individual in comparison with those experienced or anticipated through alternative opportunities... Thus from the viewpoint of the individual, willingness is the joint effect of personal desires and reluctances; form the viewpoint of the organization, it is the joint effect of objective inducements offered and burdens imposed. The measure of this net result, however, is entirely individual, personal and subjective' (pp. 85-86).

Again, we must emphasize the intrinsic individualism or liberalism of Barnard's approach. To this extent, notwithstanding his more complex appreciation of the factors which induce human cooperation and their normal existential situations than Rand allows, he can be said to follow a relatively simple cost/benefit approach to making informed choices when in engaged in organizational activities. But this would not be correct.

To see why, it is necessary to consider one of Barnard's (1938) most original and controversial contributions to organization theory: the most important executive function. "That which is unique to the executive functions, however, is that they impose the necessity of creating moral codes" (Barnard, 1938, p. 274).This idea is especially relevant to this essay, because it separates Barnard from 'objectivist' approaches:

'The most generally recognized aspect of this function [creating moral codes for others] is called securing, creating, inspiring of 'morale' in the organization. This is the process of inculcating points of view, fundamental attitudes, loyalties, to the organization... that will result in the subordinating of individual interests... to the good of the cooperative whole' (Barnard, 1938, p. 279). 
Note that this notion flatly contradicts Gomba's (2012) notion of servant leadership. Note also that this is not 'feel good' morale boosting (Vasillopulos, 2011). Barnard (1938) aimed at 'fundamental attitudes.' Only then can individuals become 'fitted for cooperation.' Rand (1957) believed, to the contrary, that material inducements would suffice given ego-driven self-interest. Far from separating the executive from moral concerns the Barnardian executive is immersed in them:

'The chief difference between the lower and higher ranks is not in the capacity of responsibility but in the conditions of moral complexity... The moral complications of the executive functions, then, can only be endured by those possessing a commensurate ability. While, on the one hand, the requisite ability without an adequate complex of moralities or without a high sense of responsibility leads to the hopeless confusion of inconsistent expediencies so often described as 'incompetence;' on the other hand, the requisite morality and sense of responsibility without commensurate abilities leads to fatal indecision or emotional and impulsive decisions, with personal breakdown and ultimate destruction of the sense of responsibility' (Barnard, 1938, p. 275-276).

This function is so critical to securing cooperation that it incorporates the idea of 'the noble lie.'

'The invention of the constructions and fictions necessary to secure the preservation of morale is a severe test of both responsibility and ability, for to be sound they must be 'just' in the view of the executive, that is, really consonant with the morality of the whole; as well as acceptable, that is, really consonant with the morality of the part, of the individual' (Barnard, p. 281).

The inculcation of moral codes has troubled many Barnard scholars, for it seems to qualify, if not destroy, Barnard's liberalism. 'Subordinate the individual' indeed! Shades of Big Brother! Barnard (1938) believed he dealt with this issue by including the chief executive in the regime of domination:

'The most important single contribution required of the executive, certainly the most universal qualification, is loyalty, domination by the organizational personality. This is the first necessity because the lines of communication cannot function at all unless the personal contributions of executives will be present at the required positions, at the times necessary, without default for ordinary personal reasons. This, as a personal qualification, is known in secular organizations as the quality of 'responsibility; in political organizations as 'regularity'; in governmental organizations as fealty or loyalty; in religious organizations as 'complete submission' to the faith and to the hierarchy of objective authority. The contribution of personal loyalty and submission is least susceptible to tangible inducements' (p. 220).

Not only does this notion undermine Rand's (1957) notion of the power of tangible inducements, it seems to place Barnard in a totalitarian universe. Shades of Darkness at Noon! Yet these fears are dramatically overdrawn, for they neglect Barnard's locus of decision, the locus of informed choice, which always remains in the brain of an individual. The organization, like the larger society, can make claims on an individual's cooperation, but coercion is always wrong and self-defeating. "Authority always lies with him to whom it applies. Coercion creates a contrary illusion; but the use of force ipso facto destroys the authority postulated" (Barnard, 1938, p. 183). This formulation recalls Barnard's definition of authority. Consider the following: "The individual is always the basic strategic factor in organization. Regardless of his history or his obligations he must be induced to cooperate, or there can be no cooperation" (Barnard, 1938, p. 139). And, "The necessity of the assent of the individual to establish authority for him is inescapable" (p. 165). And further, "An intelligent person will deny the authority of that one which contradicts the purpose of the effort as he understands it" (p. 166). And again, 'The point is that responsibility is the property of an individual by which whatever morality exists in him becomes effective in conduct' (p. 267). For Barnard, a command is an invitation to compliance. Authority only exists when the 'subordinate' agrees with the command. Coercion destroys the basis of authority and cooperation in principle. It is difficult to derive totalitarianism from such conceptions.

His crime... is his very innocence in more than one sense: the obvious innocence of the accusation lodged against him and, more relevant to his fate, his innocence of the existence of evil (Goodheart, 2006).

\section{But, What of Billy?}

'What of Billy' suggests that we are about to analyze the palpable injustice visited upon him. Here, we are concerned with justice, however, only as it impacts organizational effectiveness. Let us make clear that we are not undertaking an analysis of Billy Budd from an organizational perspective, a study which would mandate dealing with the novel as presented. Our analysis asks the question, Could a Barnardian understanding of the HMS Indomitable have prevented the series of events which led to Billy's execution? We believe, although there is no way to prove the case, it could have. Furthermore, we contend that Billy's charismatic personality, his 
status as Handsome Sailor, his intimation of Jesus - all would have been part of the transformation of the navy ship into a form of 'brotherhood,' thereby enhancing its effectiveness.

Let us begin by reiterating a cardinal fact: Billy was a remarkable sailor and everyone knew it. Melville amplifies this fact by stating that only Vere and Claggart fully appreciated it. A second point, all but ignored by literary scholars, is that the ship's crew and officers was an organization, that is, constituted of individuals committed to common purposes under hazardous conditions: the sea itself, compounded by war. A third point is that Captain Vere had almost unlimited power, including the power to execute Billy, as is well understood, but also the power to exonerate him, which has seldom if ever been remarked.

We will make the easy case first: No Claggart, no evil incarnate, no malicious conspiracy to execute Billy. Billy's beneficent influence would have pervaded the warship as effectively as it had the merchant ship. But Claggart did exist and to some extent will always exist, so his malevolence will have to be dealt with in one form or another. What could have been done to thwart his efforts to eliminate Billy? It seems to us there were several opportunities to do so. Take the case of Dansker, who knew Claggart for the villain he was. He warned Billy of the danger Claggart presented to him but said nothing to anyone else, nothing to anyone superior to Claggart. Dansker was afraid. Only Billy's surpassing innocence induced Dansker to minimal and ineffectual warning. Dansker bespeaks of an atomized crew, each sailor afraid, anxious, and alone. So pervasive was this feeling that even Billy's presence or rather Billy's presence by itself could not break the shell of fear which kept the crew atomized. Pervasive fear, which cannot but undermine the cooperation necessary for the ship's effectiveness, is a decisive failure of leadership. Barnard says in so many words that coercive systems, systems which motivate with fear, are not cooperative organizations at all. The negative impact on task completion beyond the most rudimentary, to say nothing of larger organizational objectives, is obvious. Willing cooperation is essential to organizational effectiveness and efficiency.

Other opportunities to abort Claggart's malevolent plan center on the officers, Vere's staff. To a man, they recognized, respected, and honored Billy's exceptional traits and their effect on the entire ship. No one believed he was capable of mutiny or even contemplating it. With varying degree of ineptitude, they conveyed their views to the Captain. No one persisted. No group effort was undertaken. No one said they would inform the admiralty of Vere's precipitous and reckless actions. All bowed before the power, power unjustly applied, of the captain and by so doing betrayed their honor and claim to moral status. What's more they undermined the effectiveness of their ship. How could the crew respect their officers, to say nothing of the doctor or the chaplain, when they so clearly failed to do their duty as officers and men of honor? How could the officers not been aware that their cowardly dereliction of duty would not have a negative effect on the crew and its effectiveness?

And finally Vere himself - the ultimate puzzle. Melville (1950) took pains to emphasize Vere's intelligence, refinement, sensitivity, and character - all traits which should have enabled him to see Claggart's character as clearly as he saw Billy's. Yet blithely ignoring their characters, he focused on the raw act of striking a superior and applies the death penalty. It seems to us that Vere was, for all his virtues, an incomplete man, a sum of his attributes and no core, no code with which to confront existential dilemmas. He was the antithesis of a Barnardian executive:

'The leadership which reflects the attitudes and ideals of society and its general institutions... is the aspect of individual superiority in determination, persistence, endurance, courage; that which determines the quality of action; which often is most inferred from what is not done, from abstention; which commands respect, reverence. It is the aspect of leadership we commonly imply in the word 'responsibility,' the quality which gives dependability and determination to human conduct, and foresight and ideality to purpose' (Barnard, 1938, p. 260).

Billy Budd is the tragedy of Captain Vere as much as of Billy, perhaps more. For Billy was a complete man, a constant in a Heraclitian universe. Vere, Starry Vere, aware of the possibilities Billy presented, abjured. He resisted Billy's influence on him and, what is worse, when confronted with the opportunity to recognize Billy's innocence and Claggart's guilt, he again failed. He could have become a true leader, one who creates moral codes for his officers and crew, one who embodied the organizational code of the navy. Exonerating Billy would have transformed the officers and crew into a 'brotherhood' and transformed Vere into a complete man and a leader of men. Who could doubt the positive impact of such transformations on the effectiveness and efficiency of the HMS Indomitable? Who could doubt the benefits accruing to all? 'I believe that the expansion of cooperation and the development of the individual are mutually dependent realities, and that a due proportion or balance between them is a necessary condition of human welfare' (Barnard, 1938, p. 296).

Cooperation compels changes in the motives of individuals which otherwise would not take place (Barnard, 
1938).

It is assumed that the individual situation of each of those cooperating will be improved; that is, it will be more efficient because joint effort will be more effective... The efficiency of the enterprise lies in the fact that the satisfactions to the individuals involved are more than sufficient to induce cooperation (Barnard, 1938).

\section{What of Educational Leadership?}

Schools exist to deliver educational services to students, not therapy to staff. A generalized 'caring' environment under the leadership of someone like Captain Graveling might contribute to morale and thereby have a positive effect on the delivery of educational services, but a caring environment should by no means become the over arching goal of the organization, as servant leadership suggests. Most educational reforms have been aimed at making teachers and principals more accountable for meeting educational objectives and have been critical of those who are prone to shield instructors from the rigors of their jobs. This has been the goal of many 'market oriented' reforms and their paler cousins, charter schools. We do not see how an extreme market approach as articulated by Rand (1957) could meet the multivariate and complex goals of public education. While her competitive model might increase test scores based on 'skill and drill,' it would almost inevitably ignore character building components which we believe are essential to education (Vasillopulos, 2011). It is not our purpose to evaluate these 'reforms,' all of which seem to present their own problems. We simply want to emphasize that servant leadership, due to its almost inevitable confusion of employees and students and its lack of focus on organizational objectives, is likely to create more problems than it solves. It seems to us that if we are to get beyond laundry lists of leadership attributes and beyond efforts to improve morale with 'caring and sharing' methods, a Barnardian understanding of organizations and executive functions is necessary(Vasillopulos, 2011b).

\section{References}

Barnard, C. (1938). The Functions of the Executive. Cambridge: Harvard.

Bogotch, I. (2011). A history of public school leadership. Chapel Hill: The University of North Carolina Press. http://dx.doi.org/10.1080/13632434.2011.560662

Branson, C. M. (2010). Free to become: The essence of learning and leading. In A. Normore (Ed.), Advances in Educational Administration: Global Perspectives on Educational Leadership Reform (Vol. 11). Northampton, UK: Emerald Publishing Group.

Crow, G., \& Grogan, M. (2011). The Development of leadership thought and practice in the United States. In F. English (Ed.), The sage handbook of educational leadership. Chapel Hill: The University of North Carolina Press. http://dx.doi.org/10.4135/9781412980036.n19

Edel, A. (1982). Aristotle and his philosophy. Chapel Hill: University of North Carolina Press.

English, F. (Ed.) (2011). The sage handbook of educational leadership. Chapel Hill: The University of North Carolina Press. http://dx.doi.org/10.4135/9781412980036.n22

Gomba, E. (2012). Servant leadership: A critical analysis of the theory and its Characteristics. Journal of Society and Communication, 231-260. Retrieved from http://journalofsocietyandcommunication.com/index.php/jsc/article/view/34/9

Goodheart, E. (2006). "Billy Budd” and the World's Imperfection. Sewanee Review, 114(1), 81-92.

Greenleaf, R. K. (1997). Servant Leadership. Mahwah, NJ: Paulist Press.

Hobbes, T. (2004). Leviathan: Or, the matter, forme, \& power of a Common-wealth ecclesiasticall and civill. New York: Barnes \& Noble Books. (original work published in 1651).

Melville, H. (1950). Selected tales and poems. In R. Chase (Eds.), Herman Melville selected tales and poems. New York: Rinehart and Company.

Normone, A. (2010). Global perspectives on educational leadership reform. Bingley, UK: Emerald Publishing Group.

Pinker, S. (2003). The blank slate. New York: Penguin.

Pritchett, H. P. (1971). Billy Budd: A Collection of Critical Essays. New Jersey: Englewood Cliffs.

Rand, A. (1957). Atlas shrugged. New York: Random House. 
Ruttenburg, N. (1994). Melville's handsome sailor: The anxiety of innocence. American Literature, 66(1), 83-103. http://dx.doi.org/10.2307/2927434

Schlesinger, A. (1958). The coming of the New Deal. New York: Houghton Mifflin.

Slayton, J., \& Mathis, J. (2010). Building the leaders we need: The role of presence, learning conditions, and andragogy in developing leaders who can change the face of public Pre-K through 12 education. In A. H. Normore (Ed.), Global Perspectives on Educational Leadership Reform: The Development and Preparation of Leaders of Learning and Learners of Leadership, 11 (pp. 23-45). http://dx.doi.org/10.1108/S1479-3660(2010)0000011005

Trivers, R. (1985). Social evolution. Reading, MA: Benjamin Cummings.

Vasillopulos, C. (1988). Heroism, Self-Abnegation and the Liberal Organization. Journal of Business Ethics, 7(8), 585-591. http://dx.doi.org/10.1007/BF00382790

Vasillopulos, C. (2011). The Natural Rights Basis of Aristotelian Education. Studies in Philosophy \& Education, 30(1), 19-36. http://dx.doi.org/10.1007/s11217-010-9204-9

Vasillopulos, C. (2011b). Barnard's surprise: Competence as A moral quality. International Journal of Business and Social Science, 2(12). Retrieved from http://search.proquest.com/docview/904511190?accountid=7374 